\title{
MICROBIOLOGICAL AND PARASITOLOGICAL INVESTIGATIONS IN RODENTS POSING SANITARY RISK IN ANIMAL FACILITIES
}

\author{
S. KESYAKOVA ${ }^{1}$, G. ZHELEV ${ }^{2}$, A. DIMITROVA ${ }^{1}$, M. BONOVSKA ${ }^{1}$, \\ P. SABEV ${ }^{1}$, T. LALKOVSKA ${ }^{1} \&$ P. ZHELYAZKOV ${ }^{1}$ \\ ${ }^{1}$ National Diagnostic and Research Veterinary Medical Institute, Sofia, Bulgaria; \\ ${ }^{2}$ Faculty of Veterinary Medicine, Stara Zagora, Bulgaria
}

\section{Summary}

Kesyakova, S., G. Zhelev, A. Dimitrova, M. Bonovska, P. Sabev, T. Lalkovska \& P. Zhelyazkov, 2015. Microbiological and parasitological investigations in rodents posing sanitary risk in animal facilities. Bulg. J. Vet. Med., 18, No 2, 167-172.

A total of 88 rodents - 22 Norway rats (Rattus norvegicus), 36 black rats (Rattus rattus) and 10 house mice (Mus musculus), were caught in different animal facilities and two zoos. Additionally, 10 albino rats and 10 laboratory mice from a specialised vivarium were studied. Samples of hair, intestinal tract and liver were examined microbiologically. Faecal samples from the three synanthropic rodent species were investigated for presence of helminth eggs, and diaphragms of carcasses - for presence of Trichinella larvae. Microbiological examination showed that synanthropic rodents carried enterotoxigaenic Escherichia coli, Staphylococcus aureus, Staphylococcus epidermidis strains and some bacteria such as Klebsiella pneumoniae, Citrobacter freundi, Enterococcus faecalis, Proteus spp. Moraxella atlantae, posing a potential risk for farm animal health. The detected eggs of parasites as Aspiculuris tetraptera, Hymenolepis spp., Eimeria spp., Oxyiuridae spp., were specific for synanthropic rodents.

Key words: animal facilities, rodents, sanitary risk

\section{INTRODUCTION}

In their habitat, murids spread microorganisms and parasites through both biological and mechanical routes - via their contaminated hair, nibbling on foodstuffs or food products or contaminating them directly with faeces and urine (Mesina \& Campbell, 1975; Kesyakova \& Korudzhijski, 1981; Gacheva et al., 2000; Acha \& Szyfres, 2001; Kesyakova et al., 2013).
Animal farms are artificial ecosystems, where harmful rodents are unsolicited but due to the specific environmental conditions, their populations are often numerous and flourishing. For complete and substantiated evaluation of sanitary risk posed by rodents in a given facility, one should be aware not only about the size of the respective population, but also detec- 
tion, identification and classification of microorganisms carried by rodents into pathogens and conditional pathogens is needed. Such investigations have been done by researchers in different countries (Mesina \& Campbell, 1975; Acha \& Szyfres, 2001; Francis, 2002), but in Bulgaria, such research has not been conducted for years (Kesyakova \& Korudzhijski, 1981). At the same time, modern trends for health risk assessment require control "from the stable to the table". Therefore, the microbial pathogens and parasites carried by synanthropic rodent populations in animal facilities should be recognised.

In a previous study of ours, we investigated the pathogenic microorganisms and parasites in rodents, caught in a foodprocessing enterprise (Kesyakova et al., 2013).

The aim of the present study was to investigate the prevalence of microorganisms and parasitic eggs among rodents inhabiting different animal facilities.

\section{MATERIALS AND METHODS}

Samples from synanthropic rodents caught in eleven animal premises were submitted to microbiological and parasitological examinations. The surveyed sites were as followed: cattle farm (Stara Zagora region), pig farm (Rousse region), rabbit farm (Stara Zagora region), 4 poultry farms (Chirpan, Stara Zagora and Nova Zagora regions), the city zoos in Sofia and Stara Zagora, an experimental farm for rearing of pigs, sheep, goats and poultry (Sofia region), and a vivarium for laboratory animals. A total of 88 rodents -22 Norway rats (Rattus norvegicus), 36 black rats (Rattus rattus), 10 house mice (Mus musculus), 10 albino rats and 10 laboratory mice were studied. Samples of hair, intestinal tract and liver were examined microbiologically. Faecal samples from the three synanthropic rodent species were investigated for presence of helminth eggs, and diaphragms of carcasses - for presence of Trichinella larvae. All animal facilities were free from infectious diseases at the time of survey.

The samples were analysed in the National Diagnostic and Research Veterinary Medical Institute, Bulgarian Food Agency - Sofia. Microbiological tests were run according to Bulgarian state standards as ISO 6579; 6888-02; 7251-05; 11133-1 etc. (Anonymous, 2004).

Bacteriological studies for isolation and identification of Staphylococcus spp., Streptococcus spp. and the Enterobacteriaceae family were done as per Bergey's Manual of Determinative Bacteriology (Holt et al. 1994). E. coli belonging to the ETEC pathovar were detected using agglutination kit K 88 (F 4) (Fimbrex, Vetwey, Weybridge, UK); Anti-Coli F 4 (K88) test serum (Sifin, GmbH, Berlin); Escherichia coli antigen test kit K-99 Pilitest, VMRD, US and Anti-Coli F 5 (K99) (Sifin, GmbH, Berlin). The biochemical identification was done via KBO10 Hi E. coli Identification Kit and the MICRONAUT E system (Merlin Diagnostika GmbH). Samples were tested for Salmonella spp. according to BSS EN ISO 6579/A1, Amendment 1, Appendix D (Serbezov, 1965; Bijlsma et al., 1984; Masalski et al. 1995; Francis, 2002; Bischoff et al., 2005).

The parasitological studies for parasitic eggs were performed by the Fülleborn's method. Tests of diaphragms from rats and mice for Trichinella larvae were done by the tissue compression method. 
S. Kesyakova, G. Zhelev, A. Dimitrova, M. Bonovska, P. Sabev, T. Lalkovska \& P. Zhelyazkov

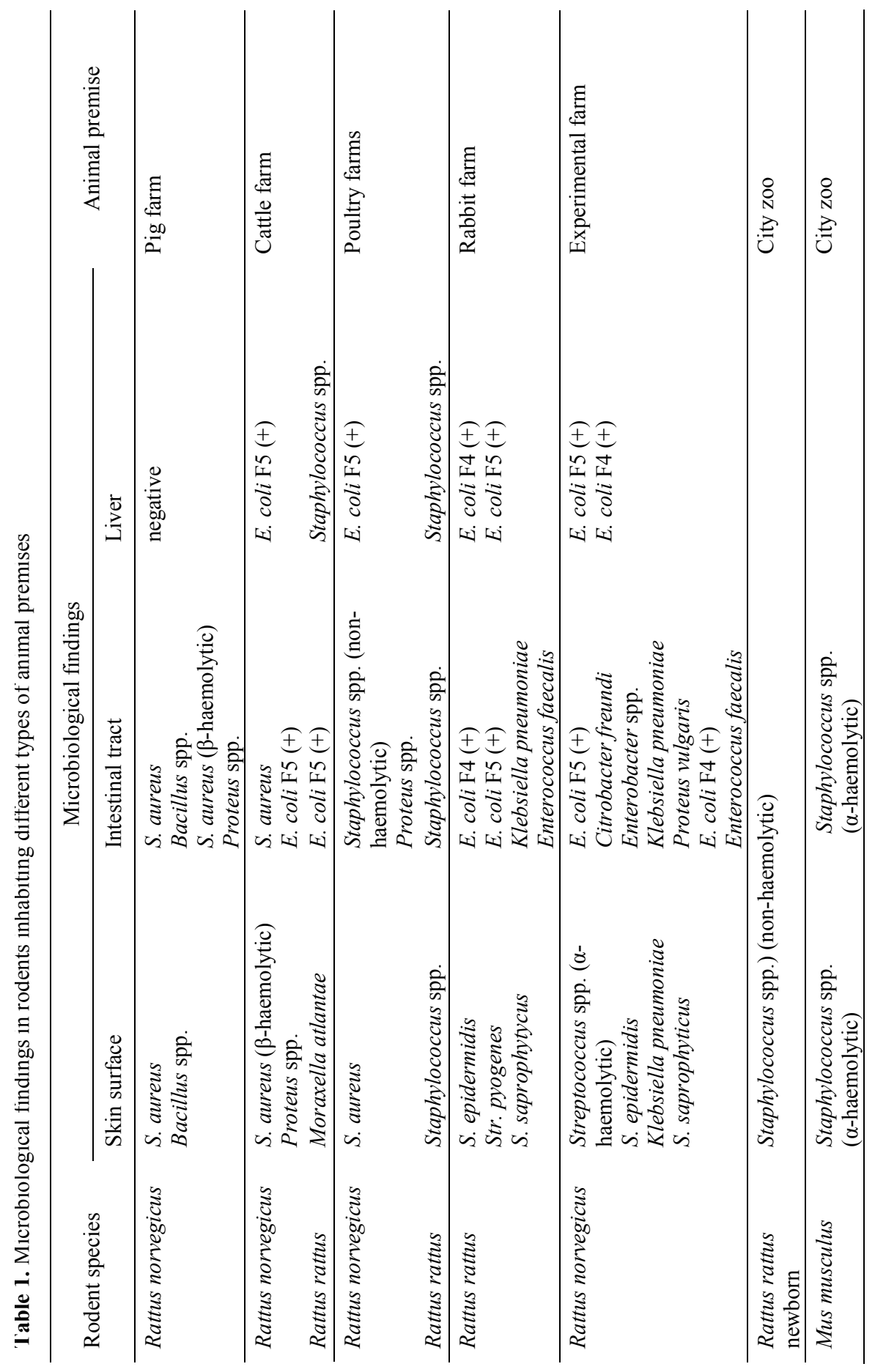

BJVM, 18, No 2 


\section{RESULTS}

The data from microbiological tests of rodents caught in the different animal premises are presented in Table 1. The results indicated that studied synanthropic rodents carried mainly conditionally pathogenic microorganisms, frequently encountered in the environment.

The results from parasitological tests of rodent intestinal content and faeces are listed in Table 2. None of studied diaphragm samples showed larvae of Trichinella.

\section{DISCUSSION}

The data from the study confirmed that the presence of enterotoxigaenic $E$. coli as well as of haemolytic Staphylococcus spp. in harmful rodent populations should not be underestimated (Mesina \& Campbell, 1975; Acha \& Szyfres, 2001; Francis, 2002; Shepard et al., 2012; Himsworth et $a l ., 2014)$. The isolation of the so-called super bacterium Klebsiella pneumoniae is another alarming sign that rodents carry microbial pathogens with potential high antimicrobial resistance. The passage of such microorganisms though the susceptible rodent population could lead to increased virulence and hence, higher risk for the health of productive animal and men. Some authors (Van De Giessen et al., 2009; Himsworth et al., 2014) reported the presence of methicillin-resistant $S$. aureus (MRSA) in Norway rats, including strains causing disease in men and farm animals. They affirmed rodents as an important source of infection, being a natural reservoir of MRSA over a prolonged period of time. Synanthropic rodents, which are the most important risk factors for contamination of animal foodstuffs, are the link in infection spread between men and animals (Himsworth et al., 2014; Van De Giessen et al., 2009).

The detection of Moraxella atlantae a bacterium carried mainly by flies - on the skin of rats confirmed once again the indirect involvement of rodents in spread mechanisms, conservation and contamination of animal facilities with this microbial pathogen. The presence of these bacteria

Table 2. Parasitological findings in the gastrointestinal tract of rodents inhabiting different types of animal premises

\begin{tabular}{lll}
\hline Rodent species & Parasitological findings & Animal premise \\
\hline $\begin{array}{l}\text { Rattus norvegicus } \\
\text { Rattus rattus }\end{array}$ & negative & Pig farm \\
\hline Rattus norvegicus & Aspiculuris tetraptera & Cattle farm \\
& Hymenolepis spp. & \\
Eimeria spp. & \\
Rattus rattus & Hymenolepis spp. & Poultry farms \\
\hline Rattus norvegicus & Eimeria spp. & \\
Rattus rattus & Aspiculuris tetraptera & Rabbit farm \\
\hline Rattus rattus & Eimeria spp. & $\begin{array}{l}\text { Vivarium for laboratory } \\
\text { rodents }\end{array}$ \\
\hline Rattus rattus - albino & Hymenolepis spp. & \\
Mus musculus - albino & Oxyiuridae spp. & \\
\hline
\end{tabular}


at the farms, sustained by the continuous contamination by rodents incurs not only health risks, but creates conditions for increased microbial load of the organism of animals. Thus the increased energy expenditure for the constant control of the microorganisms results in reduced yields and poorer economic results.

Data from parasitological tests showed that over the experimental period, rodents had no epizootological importance in none of surveyed animal facilities as parasitic diseases were concerned. The detected parasitic eggs are a specific finding for synanthropic rodents, proving once more that their populations should be kept under control through eradication.

\section{CONCLUSIONS}

The presence of rodents in animal facilities poses epizootological risks for farmed animals. The relatively most important risk is posed by rodents, inhabiting farms where multiple animal species are simultaneously housed. Norway rats (Rattus norvegicus) carried more microbial pathogen species and therefore, their presence at farms was related to higher epizootiological risk.

\section{REFERENCES}

Acha, P. N. \& B. Szyfres, 2001. Zoonoses and Communicable Diseases Common of Man and Animals $-3^{\text {rd }}$ edn, PAHO, Washington, D.C.

Anonymous, 2004. Regulation (EC) No $852 / 2004$ on the hygiene of foodstuffs. http://ec.europa.eu /food/food/biosafety/ hygienelegislation/guidance_doc_852-

2004_bg.pdf (24 March 2014, date last accesse-d).

Bijlsma, I. G. W., A. De Nijs \& J. F. Frik, 1984. Serological variants of Escherichia coli K88 antigen: Differences in adhe- sionand haemagglutination. Revue Scientifique et Technique de l'Office International des Epizooties, 3, 871-879.

Bischoff, C., J. Lqthy, M. Altwegg \& F. Baggi, 2005. Rapid detection of diarrheagenic $E$. coli by real-time PCR. Journal of Microbiological Methods, 61, 335-341.

Francis, D. H., 2002. Enterotoxigenic Escherichia coli infection in pigs and its diagnosis. Journal of Swine Health and Production, 10, 171-175.

Gacheva, N., V. Novkirishki \& V. Voynova, 2000. Epidemiological aspects of important zoonoses in the Republica of Bulgaria. DDD Bulletin, 1-2, 18-32 (BG).

Himsworth, C. G., R. R. Miller, V. Montoya, L. Hoang, M. G. Romney, G. N. Al-Rawahi, T. Kerr, C. M. Jardine, D. M. Patrick, P. Tang \& J. Scott Weese, 2014. Carriage of methicillin-resistant Staphylococcus aureus by wild urban Norway rats (Rattus norvegicus). PLoS ONE, 9, e87983. http:// www.plosone.org/article/fetchObject.action?uri=info $\% 3$ Adoi $\% 2 \mathrm{~F} 10.1371 \% 2 \mathrm{Fjou}$ rnal.pone. $0087983 \&$ representation $=P D F$ (03 July 2014 date last accessed).

Holt, J. G., N. R. Krieg, P. H. Sneart, J. T. Staley \& S. T. Williams. 1994. Bergey's Manual of Determinative Bacreriology, $9^{\text {th }}$ edn, Wiliams \& Wilkins, USA.

Kesyakova, S. \& N. Korudzhijski, 1981. Investigation on the carriership of bacteria by synanthropic rodents in industrial pig farms. Proceedings of the $5^{\text {th }}$ Congress of Microbiology, vol. II, pp. 107-111 (BG).

Kesyakova, S., M. Bonovska, H. Daskalov, P. Sabev, N. Lalkovski \& G. Zhelev, 2013. Sanitary risks in case of presence of rodents in food processing plants. Bulgarian Journal of Veterinary Medicine, 16, Suppl. 1, 238-243.

Masalski, N., Ts. Dikova, A. Kozarov, G. Georgiev \& E. Dimitrova, 1995. Detection of a verotoxin in $E$. coli strains, isolated from lambs with diarrhoeic syndrome. Veterinary Medicine (Sofia), 3, 165-166 (BG). 
Microbiological and parasitological investigations in rodents posing sanitary risk in animal facilities

Mesina, J. E. \& R. S. F. Campbell, 1975. Wild rodents in the transmission of disease to animals and man. The Veterinary Bulletin, 45, 87-97.

Serbezov, V., 1965. Investigation on wild rats from some regions of Bulgaria for endemic typhus fever and Q fever. Epidemiology, Microbiology and Infectious Diseases (Sofia), 1, 83-87 (BG).

Shepard, S. M., J. L. Danzeisen, R. E. Isaacson, T. Seemann, M. Achtman \& T. J. Johnson, 2012. Genome sequences and phylogenetic analysis of K88- and F18positive porcine enterotoxigenic Escherichia coli. Journal of Bacteriology, 194, 395-405.

Van De Giessen, A. W., M. G. van SantenVerheuve, P. D. Hengeveld, T. Bosch, E. M. Broens \& C. B. Reusken, 2009. Occurrence of methicillin-resistant Staphylococ- cus aureus in rats living on pig farms. Preventive Veterinary Medicine, 91, 270-273.

Paper received 24.03.2014; accepted for publication 13.06.2014

\section{Correspondence:}

Prof. Slaveya Kesyakova, DSc

National Diagnostic and Research Veterinary Medical Institute, Sofia, Bulgaria, e-mail: slaveia.kes@abv.bg 